\title{
Phytoplankton colonization patterns. Is species richness depending on distance among freshwaters and on their connectivity?
}

\author{
Luigi Naselli-Flores $(\mathbb{D} \cdot$ Rosa Termine $\cdot$ \\ Rossella Barone
}

Received: 10 December 2014/Revised: 30 March 2015/Accepted: 11 April 2015/Published online: 21 April 2015

(C) Springer International Publishing Switzerland 2015

\begin{abstract}
Phytoplankton assemblages in two Sicilian water bodies were compared to test the hypothesis that colonization events and the successful establishment of a new species in an aquatic ecosystem may depend on the number of water bodies in a given area and on their relative distance. The two ecosystems are both natural, shallow lakes and they are protected sites hosting a rich avifauna. Lake Biviere di Gela is located in an area with a high density of ponds, whereas Lake Pergusa is an isolated waterbody without other aquatic ecosystems in its surroundings. Both lakes had almost disappeared about 10 years ago because of the overexploitation of their main inflows. They were therefore re-filled using water from other catchments and their phytoplankton has been sampled since their re-filling. The results show that Lake Pergusa has maintained a species-poor phytoplankton assemblage since its refilling, whereas Lake Biviere di Gela has been showing progressively richer phytoplankton assemblages
\end{abstract}

Guest editors: Luigi Naselli-Flores \& Judit Padisák / Biogeography and Spatial Patterns of Biodiversity of Freshwater Phytoplankton

L. Naselli-Flores $(\bowtie) \cdot R$. Barone

Section of Botany and Plant Ecology, Department of Biological, Chemical and Pharmaceutical Sciences and Technologies, University of Palermo, Palermo, Italy e-mail: luigi.naselli@unipa.it

R. Termine

L.I.S.A. - "Kore" University of Enna, Enna, Italy during time. The composition of samples collected in nearby located temporary ponds suggests that phytoplankton in this area belongs to a species-rich metacommunity which favored its re-establishment in the lake. Aquatic ecosystems conservation plans cannot thus neglect the role of small waters located in the catchments.

Keywords Passive dispersal - Mediterranean ponds · Conductivity fluctuations · Water-level fluctuations

\section{Introduction}

Almost all freshwater aquatic ecosystems with an open water habitat host phytoplankton. Phytoplankton assemblages may quickly develop in newly created lakes and ponds immediately after their impoundment. Even "old" ecosystems with a well established community may experience immigration of new species at a quite constant rate (Padisák et al., 2010). Although these evidences are widely acknowledged among freshwater ecologists, there is a lack of studies in scientific literature about phytoplankton colonization processes and most of the information is reported in an anecdotal way. This is partly due to the relatively small dimensions of these organisms, to their cryptic method of dispersal and to the inherent difficulties in recognizing colonization events: little attention is paid to a few new species appearing annually in a list of 
phytoplankton species, especially when their contribution to total biomass is low and when studies are carried out over a period of time of a few years. More in general, for a long time studying biogeography of microorganisms has been considered worthless due to a supposed cosmopolitanism in their distribution, and only recently microbial ecologists put in discussion the real extent of this pattern (see Fontaneto \& Brodie, 2011; Incagnone et al., 2015; Padisák et al., 2015).

To better understand phytoplankton dispersal and colonization patterns, freshwater ecosystems should be considered as biological islands scattered across the land masses in a dry ocean (Ripley \& Simovich, 2009). Actually, according to island biogeography theory, valleys, promontories, mountaintops, and other isolated spaces (such as lakes and ponds) that show different biogeographic and biodiversity levels than the areas immediately surrounding them can be treated as true islands (Cox \& Moore, 2010). Accordingly, immigration and successful colonization by phytoplankton species firstly depend on their ability to disperse over the physical barrier represented by the surrounding dry land. According to Ronce (2007), dispersal can be defined as "any movement by organisms or propagules with potential consequences for gene flow across space." However, regarding phytoplankton, dispersal cannot occur as a movement performed by the organisms themselves and it needs a transporting vector (passive dispersal) to be achieved. Even if the exact passive dispersal methods are elusive (Kristiansen, 2008), both physical and biological vectors are considered suitable carriers to spread phytoplankton across space (Boo et al., 2010). Genitsaris et al. (2011a) showed that several phytoplankton species, both as living cells and as resting stages, have a high potential for wind-mediated passive dispersal. As recently reviewed by Incagnone et al. (2015), several animals (including humans) contribute to successfully disperse propagules of freshwater organisms in the same size range of living phytoplankton cells/colonies (or their resting stages) among freshwaters. Although biological vectors as aquatic birds may represent more effective dispersal vectors than wind (Rogers, 2014), only a few investigations were found in the literature addressed at considering the role of these animals as dispersal agents for phytoplankton (Kristiansen, 1996, 2008; Cellamare et al., 2010; Padisák et al., 2015).
Few attempts were made to evaluate the dispersal of phytoplankton by wind using air sampler and/or buckets containing water (Genitsaris et al., 2011b and literature therein). These investigations, while confirming the high dispersal potential of phytoplankton (Sharma \& Rai, 2011a), do not offer useful insights on phytoplankton distribution and colonization rates (i.e., the arrival and successful establishment of new species per time interval). Actually, a sharp decoupling exists between dispersal potential and actual establishment rates, and a high dispersal potential per se does not guarantee that colonization is effectively realized (Bohonak \& Jenkins, 2003). Successful colonization depends on the chances that phytoplankton organisms and propagules have i) to reach a suitable (aquatic) environment for their establishment and, once arrived, ii) to pass through a series of chemical, physical, and biological filters that may prevent their successful establishment. Apart biological features of the colonizing species and its tolerance to a determined range of physical and chemical conditions (Bennett et al., 2010; Soininen et al., 2013; Florencio et al., 2014), both regional and local factors contribute to determine the strength of this filters (Sharma \& Rai, 2011b). In the first group of factors, the altitude distribution of water bodies (Vyverman, 1992; Catalán et al., 2009; Wang et al., 2012), as well as the spatial distance among them, and thus their isolation and density in a given territory (Soininen et al., 2007; Ripley \& Simovich, 2009 and literature therein), was found to influence colonization success. Among local factors, the morphological features of the water body (e.g., surface area, depth) to be colonized (Frisch et al., 2012; Borics et al., 2015) play an important role in allowing/contrasting the establishment of immigrant species. In addition, the biotic interactions existing in a well-structured community, which historically determined its composition by strengthening the relationships existing among its members during time, generally determine a series of inhibitory effects (priority effects), against the successful establishment of recent immigrants (e.g., Louette \& De Meester, 2007; Symons \& Arnott, 2014).

The comparison of the phytoplankton assemblages in two Sicilian shallow lakes (Lake Pergusa and Lake Biviere di Gela) suggested, in accordance to the island biogeography theory, that the frequency of coloniza- 
tion events and the successful establishment of new phytoplankton species in an aquatic ecosystem may depend on the geographical distribution of water bodies (i.e., their number and relative distance in a given area: structural connectivity) and by the effective movements of individuals (or vectors) among the water bodies (functional connectivity).

Both the lakes had disappeared in the past years because of the over-exploitation of their main inflows to fulfill agriculture water demand. However, since these are protected areas, both were re-filled with water from other catchments in order to preserve the rich biota they host. This offered the opportunity to follow the pattern of changes which occurred in their phytoplankton assemblage composition over time, to perform a comparative analysis of the differences observed in these patterns and to hypothesize that species richness patterns in inland waters may depend on their degree of isolation.

\section{Materials and methods}

\section{Study sites}

The two studied lakes are both natural and shallow lakes and are well known since the antiquity. In particular, Lake Biviere di Gela is mentioned by Pliny the Elder in his Naturalis Historia, whereas Lake Pergusa is cited in the Ovid's Metamorphoses being linked to the Greek myth of Demeter-Persephone (Rigoglioso, 2005). Apart their historic value, the lakes are both protected sites hosting a rich avifauna. Lake Biviere di Gela is in the List of Wetlands of International Importance and included in the 'Ramsar Act,' whereas Lake Pergusa was designed as a Site of Community Importance under the European 'Habitat' Directive.

Lake Pergusa, located in the middle of Sicily $\left(37^{\circ} 30^{\prime} 50^{\prime \prime} \mathrm{N}, 14^{\circ} 18^{\prime} 21^{\prime \prime} \mathrm{E}\right)$, lays at the bottom of a tectonic depression and has an elliptical shape. The lake's catchment in its western part is mainly covered by Eucalyptus spp. and Pinus spp. reforestations and a few arable land, whereas the eastern side is a residential urbanized area. Lake Biviere di Gela is a costal lake $\left(37^{\circ} 01^{\prime} 20^{\prime \prime} \mathrm{N}, 14^{\circ} 20^{\prime} 30^{\prime \prime} \mathrm{E}\right)$ with an elongated shape, which lays in a depression formed by Neogene and Quaternary sedimentary deposits. According to Manno et al. (2007), the area is characterized by a single aquifer system which during the rainy season also feeds a high number $(>100)$ of temporary ponds located within the same catchment of the lake; these authors also studied in details the quality of sediments and calculated the hydrological balance of the area. The catchment of the lake is intensively cultivated and horticulture and olive grove prevail. Both the lakes have no surface outflow and no important inflow, being mainly fed by underground waters and, during the rainy season, by ephemeral surface streams. Both the lakes are subjected to a typical Mediterranean climate alternating mild relatively rainy winters with warm, dry summers. Therefore, seasonal water-level fluctuations with an amplitude of about $1 \mathrm{~m}$ characterize these two aquatic ecosystems. Water losses from the lakes include evaporation from the water surface and underground outflow to downgradient groundwater. The waters of both lakes showed quite high conductivity values $(>10$ $\mathrm{mS} \mathrm{cm}{ }^{-1}$ ) at the beginning of this century. In Lake Biviere di Gela, these values were much higher than those recorded in 1986-1987 (Barone et al., 2010). Conversely, Lake Pergusa waters were already characterized by high conductivity values since at least the end of the nineteenth century, as shown in several studies addressed at describing the cyclic red blooms due to purple sulfur bacteria which occurred in the lake (e.g., Forti, 1933). In the past 30 years, urbanization and increased agriculture needs (also due to intensive setting of greenhouses) in these areas promoted an intensive groundwater extraction (Canova et al., 2011) which likely caused the strong and quick decrease in the water levels of the lakes at the beginning of the century, menacing their existence. In particular, from 1998 to 2004, Lake Biviere di Gela was less than $1 \mathrm{~m}$ deep and the lake was divided into two smaller water bodies (one of these with a temporary occurrence), whereas Lake Pergusa showed a depth of a few centimeters from 1997 to 2003. During these periods, most of the bottom of the lakes was completely dry and the sediments were exposed to air. To counteract this tendency and to protect these historical and naturalistic sites, the lakes were re-filled using fresh waters from two dam reservoirs with much lower conductivity values $\left(<0.2 \mathrm{mS} \mathrm{cm}{ }^{-1}\right.$ from Lake Ancipa to Lake Pergusa, and $\approx 0.5 \mathrm{mS} \mathrm{cm}{ }^{-1}$ from lake Dirillo to Lake Biviere di Gela-Naselli-Flores \& Barone, 1994). This induced a quite drastic rearrangement of the biota in Lake Biviere di Gela as discussed in 
Barone et al. (2010). Moreover, the lower conductivity values allowed in the last years, the establishment of Potamogeton pusillus L. and of Spirogyra sp. along the shores of Lake Pergusa. These species, typical of freshwaters and never recorded before, were observed to form small patches in the lake from 2011 onward.

Phytoplankton sampling and limnological variables

Water samples for phytoplankton were collected in both lakes sub-superficially in a station located in the central part of the lake. At the same time, net-plankton samples were taken by towing vertically a $40-\mu \mathrm{m}$ mesh net and fixed in $4 \%$ buffered formaldehyde. Live samples were also taken for species identification using the most up-to-date phycological literature. Taxa were identified at the lowest taxonomic rank (species) in the majority of cases. However, in some cases, it was not possible and organisms were grouped into broad categories according to their size (e.g., picoplankton $=$ algae $<2 \mu \mathrm{m}$ ) or general morphology (e.g., chlorococcal algae $=$ non motile, green algae). Those groups of organisms which could not be identified under the optic microscope at species level (picoplankton and chlorococcal algae) were considered as "monospecific."

Sampling occurred irregularly in Lake Pergusa from the beginning of 2003. From March 2008 onward, after an episode of mass fish mortality, samples were regularly collected monthly. For the purposes of this study, samples collected monthly in lake Pergusa from March 2008 to December 2013 were therefore used, and phytoplankton study began 4 years after re-filling the lake and lasted 6 years. Lake Biviere di Gela was sampled monthly from January 2005 onward (only data collected up to the end of 2010 were used here). In this case, phytoplankton study started immediately after re-filling and a dataset covering 6 years was used to make the sampling time span comparable in the two lakes. In the same period (2005-2010), phytoplankton samples were also collected in five temporary ponds located, at a crescent distance, in the surroundings of Lake Biviere di Gela. These water bodies are fed by the same aquifer of Lake Biviere di Gela (Manno et al., 2007), show a comparable water chemistry and are located along a distance gradient from the eastern lake shore (Fig. 1).

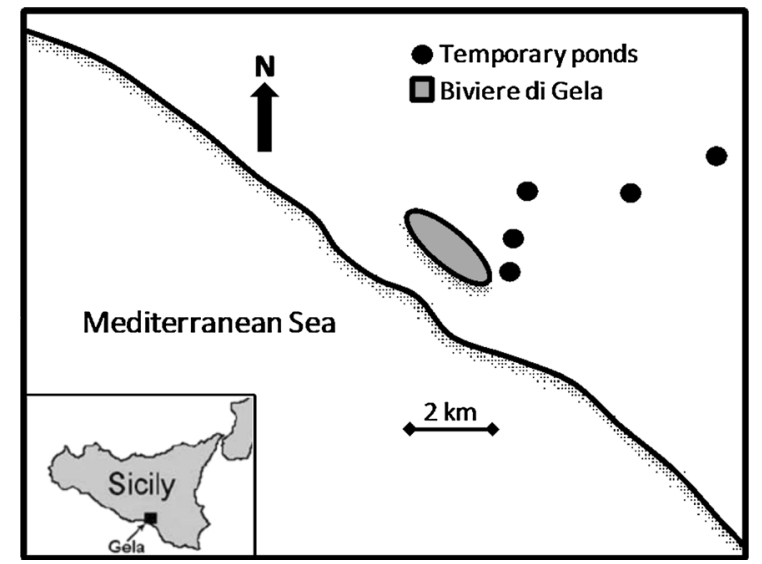

Fig. 1 Schematic map showing the location of the Lake Biviere di Gela and of the five sampled temporary ponds

Distance was measured in a straight line using Google Earth ver. 7.1.2.2041.

Phytoplankton water samples for counting were immediately preserved in Lugol's iodine solution; cell counting was performed using a Zeiss-Axiovert 100 inverted microscope in accordance with the sedimentation method developed by Utermöhl by counting all the individuals present in forty random fields at $40 \times$. Wet weight biomass was calculated from recorded abundance and specific biovolume estimates, based on simple geometric shapes (Hillebrand et al., 1999) and assuming unit specific gravity. Biomass values were used to analyze phytoplankton dynamics in the lakes as well as to evaluate the expected number of species in the two lakes using the software EstimateS 9.1.0 (Colwell, 2013).

Water electric conductivity as well as the depth of the sampling station was recorded using a YSI 556 MPS mutiparametric probe, contemporary to phytoplankton collections. Water level data for the studied periods were supplied by the respective Management Boards of the two Nature Reserves.

\section{Results}

Water level and conductivity trends

Water levels were intentionally increased in both lakes by adding freshwater from other catchments. The water level increase in Lake Biviere di Gela occurred quite abruptly at the end of 2004, and the depth of the 
lake changed from less than $1.5 \mathrm{~m}$ to almost $6 \mathrm{~m}$ in the winter 2004/2005. A more gradual re-filling occurred in Lake Pergusa and depth values increased from around 0.5 to $3 \mathrm{~m}$ in a 3 -year period. In both lakes, water levels and conductivity values showed opposite trends and were negatively correlated (Lake Biviere di Gela $r^{2}=0.95 n=107 P<0.001$; Lake Pergusa $\left.r^{2}=0.83 n=108 \quad P<0.001\right)$. In particular, a marked decrease in conductivity values was recorded in both lakes soon after their re-filling (Fig. 2). Conductivity passed from values above $10 \mathrm{mS} \mathrm{cm}^{-1}$ to values fluctuating between 1.5 and $2.0 \mathrm{mS} \mathrm{cm}^{-1}$ in Lake Biviere di Gela, and from more than $20 \mathrm{mS} \mathrm{cm}^{-1}$ to values ranging between 2.0 and $3.0 \mathrm{mS} \mathrm{cm}^{-1}$ in Lake Pergusa. Following the depth increase, also the decrease in conductivity occurred more abruptly in Lake Biviere di Gela than in Lake Pergusa.

The five temporary ponds located in the surrounding of Lake Biviere di Gela had a depth ranging between 80 and $115 \mathrm{~cm}$, diameters varying between
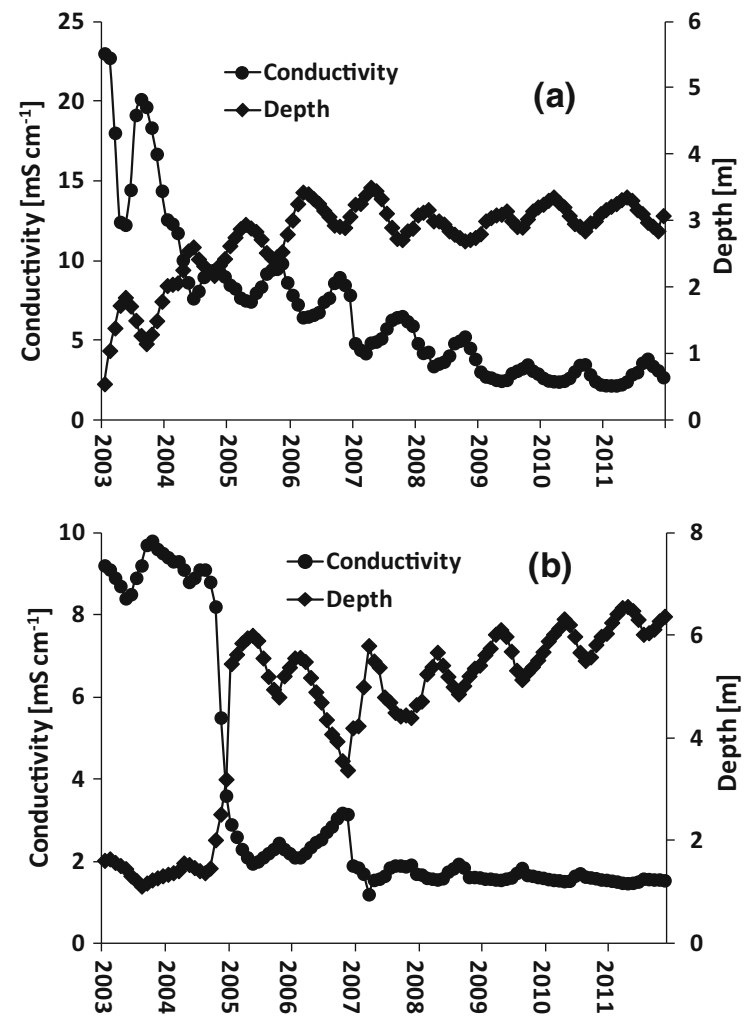

Fig. 2 Water-level fluctuations and conductivity trends in a Lake Pergusa and b Lake Biviere di Gela in the period 2003-2011
18 and $24 \mathrm{~m}$, and hydroperiod comprised between 7 and 10 months. Conductivity values in each of the five temporary ponds were quite constant in the different years of the study period. They ranged between 1.83 and $3.12 \mathrm{mS} \mathrm{cm}^{-1}$ with a trend showing higher values at the beginning and at the end of the ponding phase.

Phytoplankton dynamics in the studied lakes

The regular sampling of Lake Pergusa started in March 2008 following the concern created by a large fish-kill episode. The water of the lake appeared yellowish because of a bloom of Prymnesium parvum Carter which reached biomass values above $100 \mathrm{mg}$ $1^{-1}$ (Fig. 3a) and caused the death of the fish stocked in the lake (mainly Cyprinus carpio L.). P. parvum disappeared from counting in June and small athecate dinoflagellates and chlorococcal, monoraphidioid algae were dominant in early summer, followed by picoplanktic greens during winter 2008/2009. Virtually no phytoplankton was present in the samples from March 2009 to December 2010, when P. parvum
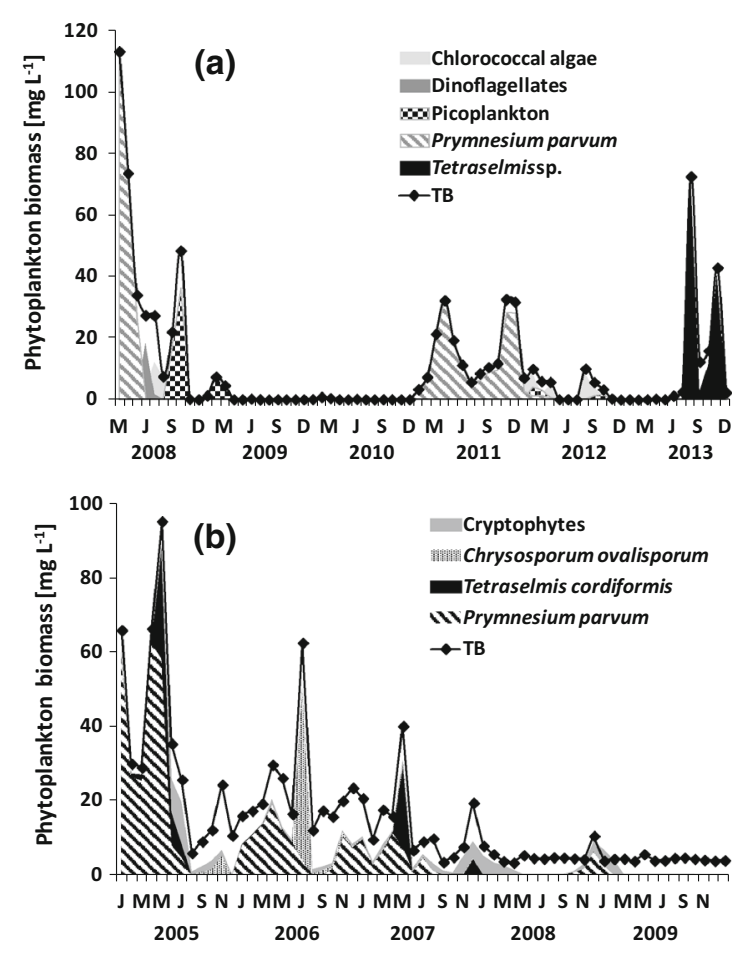

Fig. 3 Trends of phytoplankton total biomass (TB) and occurrence of dominant species in a Lake Pergusa and $\mathbf{b}$ Lake Biviere di Gela in the studied periods 
started growing again. The haptophyte was the only species present in the lake until December 2011. Biomass values showed a bimodal distribution, with the first peak (32 $\mathrm{mg} \mathrm{l}^{-1}$ ) in April 2011 and the second in November $\left(28 \mathrm{mg} \mathrm{l}^{-1}\right)$. The lowest values $(6 \mathrm{mg}$ $1^{-1}$ ) were recorded in July. The first months of 2012 showed lower biomass values and the co-occurrence of $P$. parvum, chlorococcal green algae, and picoplankton. In the period May-July, phytoplankton was again virtually absent, as well as in the period November 2012-May 2013. From June to December 2013, a bloom of Tetraselmis sp., never recorded before, occurred in the lake with two peaks, one in August $\left(70 \mathrm{mg} \mathrm{l}^{-1}\right.$ ) and the second one in November (40 $\mathrm{mg} \mathrm{l}^{-1}$ ).

Prymnesium parvum peaks were also characterizing winter/spring phytoplankton composition of Lake Biviere di Gela in the studied period (Fig. 3b). However, although showing values of $60 \mathrm{mg}^{-1}$ in spring 2005, its biomass values, as well as total phytoplankton biomass values in the lake, were progressively decreasing during time and the species almost disappeared since the end of spring 2007. Cyanobacteria increased progressively in importance after re-filling and a peak of the cyanobacterium Chrysosporum ovalisporum (Forti) E. Zapomelová, O. Skácelová, P. Pumann, R. Kopp \& E. Janecek, accompanied by Cylindrospermopsis raciborskii (Woloszynska) Seenayya \& Subba Raju, occurred in summer 2006. Also Cyanobacteria progressively decreased and in the following 2007 spring phytoplankton showed a codominance of $P$. parvum and Tetraselmis cordiformis (H.J. Carter) Stein. From the beginning of 2008 onward, a quite diversified phytoplankton was recorded in the lake with total biomass values not exceeding $5.0 \mathrm{mg} \mathrm{l}^{-1}$.

Numbers of phytoplankton taxa in the studied lakes

Figure 4 shows the species accumulation curves computed in the two studied lakes. Only 18 taxa were recorded in Lake Pergusa in the 74 samples considered for the analysis, whereas 138 taxa occurred in Lake Biviere di Gela considering the same amount of samples.

The total number of species recorded in each sample was generally much lower in Lake Pergusa (range: 1-9) than in Lake Biviere di Gela (range:

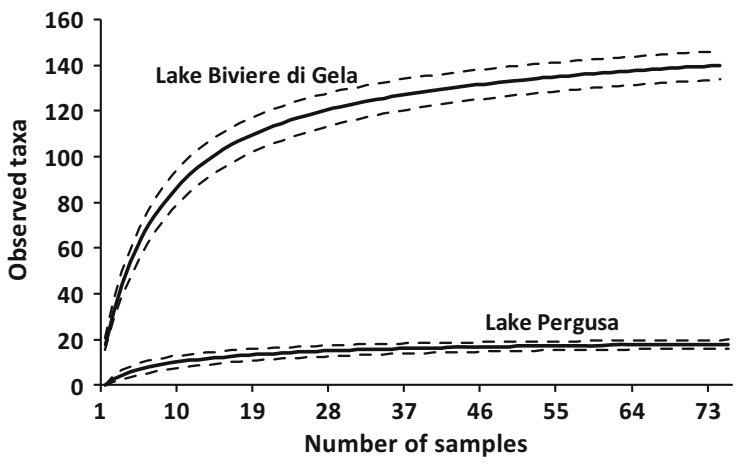

Fig. 4 Phytoplankton species accumulation curves computed in Lake Pergusa and in Lake Biviere di Gela. Dashed lines represent $95 \%$ confidence interval

6-38). Moreover, in Lake Pergusa, species number appeared to be independent from time (Fig. 5a), whereas in Lake Biviere di Gela, the number of species present tended progressively to increase $\left(r^{2}=0.59, \quad P<0.01\right)$ during the studied period (Fig. 5b). Also the number of taxa shared among consecutive samples was proportionally higher in Lake Pergusa (indicating a lower rate of floral change) than in Lake Biviere di Gela. Moreover, in this lake, the number of species occurring only once in the studied period was low indicating that the most of the immigrants successfully established a population. In addition, an increasing number of species contemporary present in the nearby temporary ponds during their ponding phase were recorded (Fig. 6). Also, the number of species contemporary occurring in Lake Biviere di Gela and in each of the five sampled temporary ponds showed a decreasing trend as the distance of the pond from the lake shore was increasing.

\section{Discussion}

As postulated by the theory of insular biogeography (Whittaker \& Fernandez-Palacios, 2007), the increasing distance between a secluded area and the source of colonists is one of the major variables affecting the immigration/emigration patterns and ultimately the species numbers in a given ecosystem. The so-called "distance effect" was experimentally tested by Simberloff \& Wilson (1969) on arthropod assemblages inhabiting mangrove islands in Florida. These authors 
Fig. 5 Species numbers recorded in a Lake Pergusa and in b Lake Biviere di Gela and nearby ponds over a period of 6 years
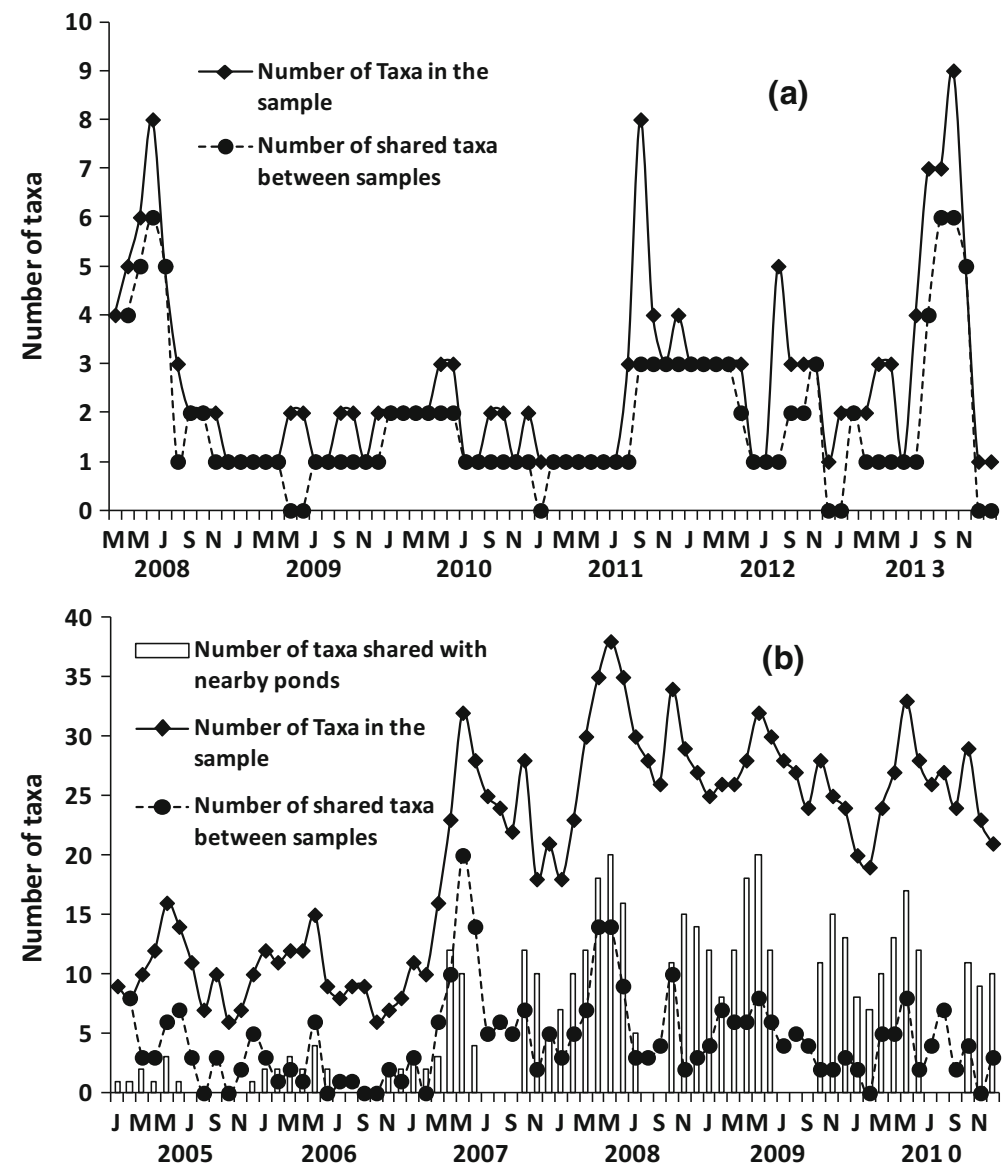

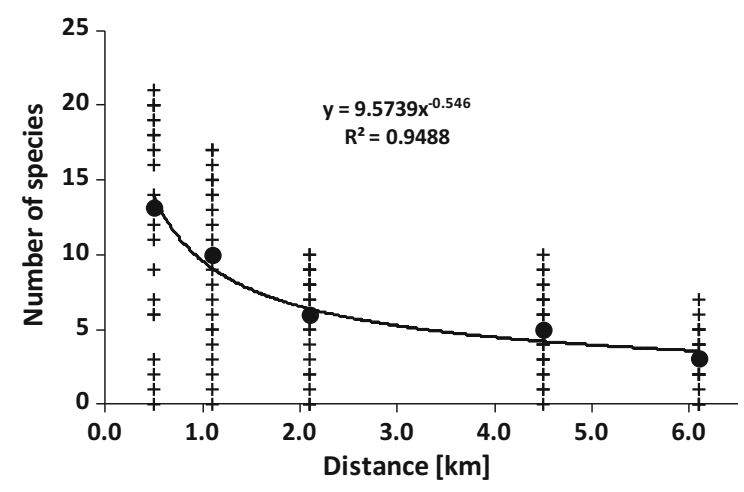

Fig. 6 Number of species shared between Lake Biviere di Gela and the nearby ponds ordered along a distance gradient. The dots indicate the average number of shared species between the lake and the single pond

demonstrated that more isolated islands are less likely to receive immigrants than less isolated islands. Since then, several studies have shown that distance effect plays a role in the distribution of insular species especially as regard birds (e.g., Nores, 1995) and terrestrial arthropods (e.g., Agnarsson et al., 2014). Moreover, as reviewed by Incagnone et al. (2015, and literature therein), relative distance among ponds has been often considered an important factor when colonization patterns of freshwater macrophyte and crustaceans were analyzed. In theory, such effect should also be true for phytoplankton as suggested by Padisák et al. (2015), but unfortunately no data on this topic were found in the scientific literature.

By comparing the results on the two studied lakes, it clearly appeared that Lake Pergusa had a quite species-poor phytoplankton assemblage with long periods characterized by the virtual absence of species, whereas Lake Biviere di Gela showed a species-rich phytoplankton and a quite high rate of floral change from year to year. The lakes apparently shared a common recent history: both were close to disappear, both showed quite high waters conductivity values which strongly decreased after the water bodies were 
re-filled with freshwaters and both showed blooms of Prymnesium parvum after their re-filling. The changes experienced by the biota of Lake Biviere di Gela were analyzed in details in Barone et al. (2010). These authors recorded an impoverishment of the phytoplankton richness in the years immediately after the refilling had occurred and a significant increase in total phytoplankton biomass compared with that observed during a survey carried out in 1986-1987. These changes were mainly attributed to the decrease in water level and the consequent disappearing of the rich submerged macrophyte belts which characterized the lake. However, the macrophyte spontaneously recovered in the lake and since 2007 onward they progressively re-colonized the lake. Starting from the same period, phytoplankton species richness, as well as its total biomass values, came back to values comparable to those recorded in 1986-1987.

Phytoplankton data recorded in 1986-1987 are also available for Lake Pergusa (Calvo et al., 1993). Conductivity values in that period were ranging between $27 \mathrm{mS} \mathrm{cm}^{-1}$ in spring and $42 \mathrm{mS} \mathrm{cm}^{-1}$ in summer. In spite of these quite high values, 14 phytoplankton taxa were recorded in the lake, including species typically occurring in freshwater (e.g., Botryococcus braunii, Oocystis sp., Euglena sp.), even though with very low biomass values. The present study, covered several years during which conductivity values progressively decreased, reaching values, from 2009 onward, comparable to those shown by the species-rich Biviere di Gela in 1986-1987.

Although high conductivity is considered an important factor affecting phytoplankton species diversity in inland waters (e.g., Padisák et al., 2003; Jeppesen et al., 2015), the species numbers recorded in Lake Pergusa in the studied period are even lower than those recorded in 1986-1987 when much higher conductivity values were measured.

The high conductivity values recorded in Lake Biviere di Gela before its re-filling was likely connected to the water level decrease experienced by the lake which allowed seawater intrusion (Manno et al., 2007). The addition of freshwater re-established water levels and the underground outflow to the sea, which reduced seawater intrusion and caused the abrupt decrease in conductivity observed when the refilling occurred. Conversely, the decrease in conductivity recorded in Lake Pergusa was due to the dilution effect caused by the addition of low-conductivity waters and showed a more gradual decrease, which may have slowed down the immigration of new phytoplankton taxa. However, although the values recorded from 2009 onward (below $3 \mathrm{mS} \mathrm{cm}^{-1}$ ) are compatible with the occurrence of several "freshwater" taxa (Naselli-Flores, 1999: Padisák et al., 2003), phytoplankton species richness remained low even when the "conductivity barrier" was removed and an increase in species number could be expected.

Fluctuations in conductivity values may have favored the occurrence in both lakes of Prymnesium parvum. This haptophyte has broad osmotic tolerance showing small variations in growth rate across a wide range of salinities. Moreover, it is well known to produce toxins which have allelopathic and grazing deterrent properties which contribute to give raise to dense, monospecific blooms (Granéli et al., 2012). This can have affected phytoplankton species richness in the studied ecosystems. However, both the lakes experienced such blooms and therefore this excludes the long-term effect on Lake Pergusa phytoplankton species richness as it was observed in the studied period.

Macrophyte cover and zooplankton grazing can also affect phytoplankton diversity but their influence has been shown to be much weaker in warmer climate (Muylaert et al., 2010 and literature therein). However, even considering a strong effect exerted from zooplankton grazing on phytoplankton diversity, it is difficult to explain such very low phytoplankton species numbers and biomass values as those recorded in Lake Pergusa from April 2009 to December 2010.

The observed phytoplankton colonization patterns in the two studied lakes could thus be related to their different degree of isolation. Lake Pergusa is an isolated water body at the bottom of a tectonic depression and no water bodies were found in its surroundings. Conversely, Lake Biviere di Gela can be considered the remnant of a much more extended system of wetlands which occupied the alluvial planes along the south-eastern part of Sicily. The plane located in the north part of the lake represents an important area for ponds and still hosts a welldeveloped network of hundreds of permanent and temporary ponds. Only a small percentage of these ponds was sampled in the present study and it is not possible to exactly establish from which of these ponds phytoplankton species found in Lake Biviere di Gela originated. However, all these environments host 
a huge number of waterbirds both in winter and in summer and the area was designated as a "Ramsar site." These animals actively move among the ponds. Passive dispersal of phytoplankton both as resting stages and as living cells has been frequently documented in literature (e.g., Genitsaris et al., 2011a; Sharma \& Rai, 2011b), and waterbirds were found to be important vectors allowing passive dispersal of freshwater plankton both on their legs and feathers and/or in the gut. Padisák et al. (2015, and literature therein) reviewed phytoplankton dispersal mechanisms and showed that several species can easily achieve short-distance dispersal, even as living cells, thanks to adaptations to survive desiccation for a few hours as they are transported by birds. The composition of phytoplankton samples collected in five of these nearby temporary ponds suggests that Lake Biviere of Gela and the temporary pond system in its surrounding form a single reservoir of biodiversity hosting a rich and well-diversified metacommunity. Birds can easily cover this distance in a few minutes and they likely do it several time a day as they pasture different water bodies (B. Massa, pers. comm.).

Species dispersal occurring in a network of freshwater habitats has been shown to minimize the fragmentation of metacommunities, thus counteracting local extinctions (Florencio et al., 2014). Moreover, species belonging to the same metacommunity have also more chances to minimize eventual priority effects caused by local adaptations (Incagnone et al., 2015).

As already shown for Lake Kastoria by MoustakaGouni et al. (2012), the metacommunity inhabiting the network of ponds located in the surroundings of Lake Biviere di Gela may have thus supplied the phytoplankton species which re-colonized the lake and favored the re-establishment of a species-rich phytoplankton assemblage similar to that recorded in 1986-1987 (Barone et al., 2010). The re-colonization trend, as described by the number of species recorded in the phytoplankton samples collected in lake Biviere di Gela, is generally increasing in the studied period although in the years 2008-2011 a decrease occurred, probably due to a progressively strengthening of priority effects as the complexity of phytoplankton structure increased (Ingagnone et al., 2015).

Conversely, the more isolated Lake Pergusa, although its re-filling occurred 3 years earlier than
Lake Biviere di Gela and its waters experienced a strong decrease in conductivity values, still showed a very species-poor phytoplankton assemblage and very little inter-annual changes in its composition. Even this lake hosts several bird species but the composition of its avifauna showed a higher prevalence of piscivores than herbivores birds, especially after blooms of Prymnesium parvum started occurring in the lake (Barone et al., 2008). The isolated geographical position of the lake and the composition of the avifauna may have thus had a role in the low phytoplankton richness recorded in the lake by avoiding or slowing down the arrival of new colonizers even after conductivity values decreased.

The results achieved in the present study suggested that the geographical distribution of water bodies in a given area can be important to ensure short-distance dispersal of phytoplankton among these aquatic ecosystems, contributing to the success of colonization, or re-colonization, of new environments by immigrants. However, these data cannot be considered exhaustive. Although a distance effect (a lower number of species shared among Lake Biviere di Gela and the surrounding ponds as their distance from the lake progressively increases) was observed in our study, a clear and definitive demonstration that this is the driver which allowed a successful phytoplankton re-colonization of the studied lake would require more information about species composition and dynamics in a higher number of ponds and under different climatic templates. Moreover, the mechanisms and processes that maintained a so low number of species in Lake Pergusa are still largely unknown: several other aquatic environments in Sicily show a similar degree of isolation but they show a much higher phytoplankton richness.

\section{Final Remarks}

Although more research is needed to fully understand the role of dispersal and colonization processes in phytoplankton ecology, the data shown in this paper support the importance of preserving small freshwater habitats (both temporary and permanent) from accidental and/or deliberate destruction. Freshwater biota is the most threatened compartment of the biosphere (Strayer \& Dudgeon, 2010). Pond networks (i.e., ponds located within a distance that can be easily and 
quickly covered by dispersal vectors) may strongly contribute to preserve freshwater species richness and there is an urgent need to emphasize their role of potential "biodiversity refugia" in conservation plans. In spite of the high biodiversity they host (NaselliFlores \& Barone, 2012), the number of ponds, especially temporary ones, has been drastically reduced in the last decades all over the world and at a very fast rate due to climate change, to the increased demand of land for agriculture and urban development, and to the over-exploitation of water resources. As regard, Italy, Stoch \& Naselli-Flores (2014) reported a disappearing rate of these environments varying between 60 and $80 \%$ every 30 years. The resulting increased geographical isolation of temporary ponds, may likely lead to a loss of connectivity among freshwater habitats, to an increased fragmentation of metacommunities and, ultimately, enhance both local and global extinction of species.

Acknowledgments The authors wish to thank two anonymous reviewers whose comments contributed to improve an early draft of the manuscript, and Prof. Bruno Massa (University of Palermo) for his support and advices. The study was carried out with the contribution of a grant from the University of Palermo (2012-ATE-0148).

\section{References}

Agnarsson, I., R.-C. Cheng \& M. Kuntner, 2014. A multi-clade test supports the intermediate dispersal model of biogeography. PLoS One 9: e86780.

Barone, R., R. Termine \& B. Massa, 2008. Remarks on a Prymnesium parvum bloom in Lake Pergusa (Enna, Sicily) and its consequences on the fauna (in Italian). Naturalista Siciliano 32: 187-200.

Barone, R., G. Castelli \& L. Naselli-Flores, 2010. Red sky at night cyanobacteria delight: the role of climate in structuring phytoplankton assemblage in a shallow, Mediterranean lake (Biviere di Gela, southeastern Sicily). Hydrobiologia 639: 43-53.

Bohonak, A. J. \& D. G. Jenkins, 2003. Ecological and evolutionary significance of dispersal by freshwater invertebrates. Ecology Letters 6: 783-796.

Bennett, J. R., B. F. Cumming, B. K. Ginn \& J. P. Smol, 2010. Broad-scale environmental response and niche conservatism in lacustrine diatom communities. Global Ecology and Biogeography 19: 724-732.

Boo, S. M., H. S. Kim, W. Shin, G. H. Boo, S. M. Cho, B. Y. Jo, J.-H. Kim, J. H. Kim, E. C. Yang, P. A. Sivers, A. P. Wolfe, D. Bhattacharya, R. A. Andersen \& H. S. Yoon, 2010. Complex phylogeographic patterns in the freshwater alga Synura provide new insights into ubiquity vs. endemism in microbial eukaryotes. Molecular Ecology 19: 4328-4338.
Borics, G., B. Tóthmérész, G. Várbíró, I. Grigorszky \& J. Görgényi, 2015. Area requirements of algae living in limnetic ecosystems-a neglected aspect of aquatic sciences. Hydrobiologia (this volume).

Calvo, S., R. Barone, L. Naselli-Flores, C. Fradà-Orestano, G. Dongarrà, A. Lugaro \& G. Genchi, 1993. Limnological studies on lakes and reservoirs of Sicily. Naturalista Siciliano 17 (Suppl.): 1-292.

Canova, F., C. Tolomei, S. Salvi, G. Toscani \& S. Seno, 2011. Land subsidence and active tectonics of a foreland area from SBAS-DInSAR technique, Hyblean Plateau, SE Sicily. Scientifica Acta 5: 14-17.

Catalán, J., M. G. Barbieri, F. Bartumeus, P. Bitusík, I. Botev, A. Brancelj, D. Cogălniceanu, M. Manca, A. Marchetto, N. Ognjanova-Rumenova, S. Pla, M. Rieradevall, S. Sorvari, E. Stefková \& E. Stuchlık, 2009. Ecological thresholds in European alpine lakes. Freshwater Biology 54: 2494-2517.

Cellamare, M., M. Leitão, M. Coste, A. Dutartre \& J. Haury, 2010. Tropical phytoplankton taxa in Aquitaine lakes (France). Hydrobiologia 639: 129-145.

Colwell, R. K. 2013. EstimateS: Statistical estimation of species richness and shared species from samples. Version 9. User's Guide and application. Published at: http://purl. oclc.org/estimates.

Cox, C.B. \& P.D. Moore, 2010. Biogeography: An Ecological and Evolutionary Approach. John Wiley \& Sons, Hoboken: $506 \mathrm{pp}$.

Florencio, M., C. Díaz-Paniagua, C. Gómez-Rodríguez \& L. Serrano, 2014. Biodiversity patterns in a macroinvertebrate community of a temporary pond network. Insect Conservation and Diversity 7: 4-21.

Fontaneto, D. \& J. Brodie, 2011. Why biogeography of microorganisms? In Fontaneto, D. (ed.), Biogeography of Microscopic Organisms. Is Everything Small Everywhere? Cambridge University Press, Cambridge.

Forti, A., 1933. Il fenomeno del lago di sangue nello stagno di Pergusa in Sicilia alla metà di settembre 1932. Nuovo Giornale Botanico Italiano 40: 76-78.

Frisch, D., K. Cottenie, A. Badosa \& A. J. Green, 2012. Strong spatial influence on colonization rates in a pioneer zooplankton metacommunity. PLoS One 7: e40205.

Genitsaris, S., K. A. Kormas \& M. Moustaka-Gouni, 2011 a. Airborne algae and cyanobacteria: occurrence and related health effects. Frontiers in Biosciences 3: 772-787.

Genitsaris, S., M. Moustaka-Gouni \& K. A. Kormas, 2011 b. Airborne microeukaryote colonists in experimental water containers: diversity, succession, life histories and established food webs. Aquatic Microbial Ecology 62: 139-152.

Granéli, E., B. Edvardsen, D. L. Roelke \& J. A. Hagström, 2012. The ecophysiology and bloom dynamics of Prymnesium spp. Harmful Algae 14: 260-270.

Hillebrand, H., C. D. Dürselen, D. Kirschtel, U. Pollingher \& T. Zohary, 1999. Biovolume calculation for pelagic and benthic microalgae. Journal of Phycology 35: 403-424.

Incagnone, G., F. Marrone, L. Robba, R. Barone \& L. NaselliFlores, 2015. How do freshwater organisms cross the "dry ocean"? A review on passive dispersal and colonization processes with a special focus on temporary ponds. Hydrobiologia 750: 103-123.

Jeppesen, E., S. Brucet, L. Naselli-Flores, E. Papastergiadou, K. Stefanidis, T. Nõges, P. Nõges, J. L. Attayde, T. Zohary, J. 
Coppens, T. Bucak, R. F. Menezes, F. R. S. Freitas, M. Kernan, M. Søndergaard \& M. Beklioğlu, 2015. Ecological impacts of global warming and water abstraction on lakes and reservoirs due to changes in water level and related changes in salinity. Hydrobiologia 750: 201-227.

Kristiansen, J., 1996. Dispersal of freshwater algae—a review. Hydrobiologia 336: 151-157.

Kristiansen, J., 2008. Dispersal and biogeography of silicascaled chrysophytes. Biodiversity and Conservation 17: 419-426.

Louette, G. \& L. De Meester, 2007. Predation and priority effects in experimental zooplankton communities. Oikos 116: 419-426.

Manno, E., M. Vassallo, D. Varrica, G. Dongarrà \& S. Hauser, 2007. Hydrogeochemistry and water balance in the coastal wetland area of "Biviere di Gela", Sicily, Italy. Water, Air \& Soil Pollution 178: 179-193.

Moustaka-Gouni, M., E. Michaloudi, K. A. Kormas, M. Katsiapi, E. Vardaka \& S. Genitsaris, 2012. Plankton changes as critical processes for restoration plans of lakes Kastoria and Koronia. European Water 40: 43-51.

Muylaert, K., C. Pérez-Martínez, P. Sánchez-Castillo, T. L. Lauridsen, M. Vanderstukken, S. A. J. Declerck, K. Van der Gucht, J.-M. Conde-Porcuna, E. Jeppesen, L. De Meester \& W. Vyverman, 2010. Influence of nutrients, submerged macrophytes and zooplankton grazing on phytoplankton biomass and diversity along a latitudinal gradient in Europe. Hydrobiologia 653: 79-90.

Naselli-Flores, L., 1999. Limnological aspects of Sicilian reservoirs: a comparative ecosystemic approach. In Tundisi, J. G. \& M. Straškraba (eds), Theoretical Reservoir Ecology and its Applications. Backhuys Publishers, Leiden: 283-311.

Naselli-Flores, L. \& R. Barone, 1994. Relationship between trophic state and plankton community structure in $21 \mathrm{Si}$ cilian dam reservoirs. Hydrobiologia 275(276): 197-205.

Naselli-Flores, L. \& R. Barone, 2012. Phytoplankton dynamics in permanent and temporary Mediterranean waters: is the game hard to play because of hydrological disturbance? Hydrobiologia 698: 147-159.

Nores, M., 1995. Insular biogeography of birds on mountaintops in North Western Argentina. Journal of Biogeography 22: 61-70.

Padisák, J., G. Borics, G. Fehér, I. Grigorszky, I. Oldal, A. Schmidt \& Z. Zámbóné-Doma, 2003. Dominant species and frequency of equilibrium phases in late summer phytoplankton assemblages in Hungarian small shallow lakes. Hydrobiologia 502: 157-168.

Padisák, J., É. Hajnal, L. Krienitz, J. Lakner \& V. Üveges, 2010. Rarity, ecological memory, rate of floral change in phytoplankton - and the mystery of the Red Cock. Hydrobiologia 653: 45-64.

Padisák, J., G. Vasas \& G. Borics, 2015. Phycogeography of freshwater phytoplankton-traditional knowledge and new tools. Hydrobiologia. doi:10.1007/s10750-015-2259-4.
Rigoglioso, M., 2005. Persephone's Sacred Lake and the Ancient female mystery religion in the womb of Sicily. Journal of Feminist Studies in Religion 21: 5-29.

Ripley, B. J. \& M. A. Simovich, 2009. Species richness on islands in time: variation in ephemeral pond crustacean communities in relation to habitat duration and size. Hydrobiologia 617: 181-196.

Rogers, D. C., 2014. Larger hatching fractions in avian dispersed anostracan eggs (Branchiopoda). Journal of Crustacean Biology 34: 135-143.

Ronce, O., 2007. How does it feel to be like a rolling stone? Ten questions about dispersal evolution. Annual Review in Ecology, Evolution and Systematics 38: 231-253.

Sharma, N. K. \& A. K. Rai, 2011a. Algal particles in the atmosphere. In Nriagu, J. O. (ed.), Encyclopedia of Environmental Health, Vol. 1. Elsevier, Burlington: 64-70.

Sharma, N. K. \& A. K. Rai, 2011b. Biodiversity and biogeography of microalgae: progress and pitfalls. Environmental Reviews 19: 1-15.

Simberloff, D. \& E. O. Wilson, 1969. Experimental zoogeography of islands - colonization of empty islands. Ecology 50: 278-296.

Soininen, J., R. McDonald \& H. Hillebrand, 2007. The distance decay similarity in ecological community. Ecography 30 : $3-12$.

Soininen, J., J. Korhonen \& M. Luoto, 2013. Stochastic species distributions are driven by organism sizes. Ecology 94 : 660-670.

Stoch, F. \& L. Naselli-Flores, 2014. Temporary waters: biodiversity, functional ecology, vulnerability and susceptibility to climate change (in Italian). Biologia Ambientale 28(87): 92.

Strayer, D. L. \& D. Dudgeon, 2010. Freshwater biodiversity conservation: recent progress and future challenges. Journal of the North American Benthological Society 29: 344-358.

Symons, C. C. \& S. E. Arnott, 2014. Timing is everything: priority effects alter community invasibility after disturbance. Ecology and Evolution 4: 397-407.

Vyverman, W., 1992. Altitudinal distribution of non-cosmopolitan desmids and diatoms in Papua New Guinea. British Phycological Journal 27: 49-63.

Wang, J., J. Soininen, Y. Zhang, B. Wang, X. Jiang \& J. Shen, 2012. Patterns of elevational beta diversity in micro- and macroorganisms. Global Ecology and Biogeography 21: 743-750.

Whittaker, R. J. \& J. M. Fernandez-Palacios, 2007. Island Biogeography. Ecology, Evolution and Conservation, 2nd ed. Oxford Univeristy Press, Oxford. 